\title{
Tourists' shopping experiences at street markets: Cross-country research
}

\author{
Antónia Correia ${ }^{\mathrm{a}, \mathrm{b}, *}$, Metin Kozak $^{\mathrm{c}}$

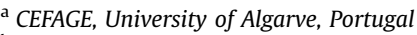 \\ ${ }^{\mathrm{b}}$ Universidade Europeia, Portugal \\ ${ }^{\text {c } S c h o o l ~ o f ~ T o u r i s m ~ a n d ~ H o s p i t a l i t y ~ M a n a g e m e n t, ~ D o k u z ~ E y l u l ~ U n i v e r s i t y, ~} 35680$ Izmir, Turkey
}

\section{H I G H L I G H T S}

- The study answers the call for research about shopping behaviour on street markets in a tourist context.

- The study offers a comparative analysis between Portugal and Turkey.

- The model considers the influence of status consciousness and moral values.

- Street markets act as an attraction; nevertheless, more proactive actions should be taken.

- The study offers a different perspective on such behaviours to revive the nature of shopping experiences.

\section{A R T I C L E I N F O}

\section{Article history:}

Received 13 April 2015

Received in revised form

1 February 2016

Accepted 20 March 2016

Available online 7 April 2016

\section{Keywords:}

Shopping behaviour

Tourist motivations

Street markets

Counterfeit

Algarve, Portugal and Bodrum

Turkey

\begin{abstract}
A B S T R A C T
Considering shopping as one of the most important motivations for travel, this study focuses on tourists' shopping attitudes towards street markets while on a vacation. Specifically, this study proposes and tests a conceptual model that assesses how price consciousness and perceived utility, as critical drivers of attitudes in street markets, may influence tourist satisfaction and future intentions. As opposed to the structure of previous research, this study is also based on a cross-national comparative study conducted among foreign tourists visiting Algarve, Portugal and Bodrum, Turkey, in the summer of 2011. Study findings confirm that price and utility perceptions are the most important marketplace cues and higher level of satisfaction moderates tourists' willingness to return or recommend street markets in both destinations.
\end{abstract}

๑) 2016 Elsevier Ltd. All rights reserved.

\section{Introduction}

Shopping is a crucial part of tourists' experience. Street and night markets are considered as the way to revive countries' culture and one of the most popular attractions within international tourists (Chang, Min, Lin, \& Chiang, 2007; Henderson, Chee, Mun, \& Lee, 2011; Kikuchi \& Ryan, 2007). Tourists prefer to shop in spaces where they are able to interact with natives to learn about local cultures (Timothy \& Butler, 1995). Being aware of this reality, tourism destination managers strive to keep street markets alive, where tradition and heritage abound. Street markets or bazaars are

\footnotetext{
* Corresponding author. CEFAGE, University of Algarve and Universidade Europeia, Portugal.

E-mail address: ahcorreia@gmail.comm (A. Correia).
}

understood as generally dedicated to shopping for leisure. However, street markets usually adopt a very peculiar type of transaction, and bargain and counterfeit products are the axes of a business where legal norms are abided to ensure a genuine experience for tourists. The prejudice around counterfeits does not damage the image of these street markets.

Examples of the success of street markets where counterfeits are sold are everywhere. In a particular reference to Portugal, the "thieve market" is a street market where counterfeit products are tolerated due to the number of visitors this ancient market registers. In Turkey, the Grand Bazaar is a must-visit place in Istanbul, and even if it has plenty of counterfeit products, it works as a visiting card of the city. In fact, counterfeiting and tourism are phenomena that date back to ancient times. While the history of tourism began in the sixth century B.C. in Babylon, counterfeiting 
started in the 13th century (A.D.), and both grew exponentially. Interpol (2015) estimates that counterfeits account for more than US\$1.7billion at U.S. borders. Therefore, counterfeit transactions can be considered a powerful force within world commerce. The tourism industry is also a major contributor to global GDP, accounting for 9.5\% (World Travel and Tourism Council, 2015). Both phenomena play a major role in the socio-economic development of some communities, although on opposite axes. This impact is even more relevant where both phenomena are operating at the same time.

On the one hand, the results of past research demonstrate that shopping is one of the major motivations for tourists (Turner \& Reisinger, 2001; Wang, 2004), accounting for a significant part of tourist expenditure (Bojanic, 2011; Kinley, Josiam, \& Kim, 2002). Tourists shopping behaviour were supported as a stimulus to novelty seeking behaviour (Chang \& Chiang, 2006), the search for their self-identity (Chang \& Hsieh, 2006). However, the research into tourism-related shopping explaining tourists' preferences and behaviours is still an emergent topic (Oh, Lehto, \& O'Leary, 2004; Lloyd, Yip, \& Luk, 2011). On the other hand, although the current body of literature yields several examples including black markets (Lehmann, 1980), harassment (Kozak, 2007), sex and prostitution (Ryan \& Kinder, 1996; Harrison, 1994), and drug use (Uriely \& Belhassan, 2006), the empirical investigation of illicit behaviour by tourists is still limited. This lack of research is also evident on the subject of street markets (Bian \& Veloutsou, 2007). Bearing this in mind, this study attempts to contribute to the call for research about purchasing shopping experiences in street markets in a tourism context.

The trigger for developing this research has arisen from the evidence that tourists tend to adopt quite different behaviours while on holidays, particularly while shopping (Yuksel, 2004; Kozak \& Tasci, 2005). Jansen-Verbeke (1994) identifies several major tourist shopping motivations: experiencing the specific identity of the destination; taking advantage of the bargain prices offered, of the exchange rate, and of the social cues of the shopping experience. The bargaining effect of tourism-related shopping has also been discussed recently by Kozak (2015), who argues that tourists are more prone to bargain while on holidays than in their home countries. In another vein, consumer attitudes and motives towards street markets vary widely, for example from price to social acceptability - where any illegality is excused by the commonplace nature of these behaviours in society (AntiCounterfeiting Group, 2009).

In addition, most of the literature on both topics focuses on a single geographical context (Veloutsou \& Bian, 2008). This study goes beyond a narrow geographical focus to offer a comparative analysis between two of the most important counterfeit paradises for tourists, namely Portugal and Turkey. This evidence illuminates the contribution of this research to the body of knowledge in two of the oldest headaches of humankind - tourism and counterfeiting. For the purpose of this study, the reality of street markets, where counterfeits abound, is accepted without prejudice, as in the study carried out by Gentry, Putrevu, Shultz, and Commuri (2001). As such, the focus of the study includes tourists who consciously seek out street markets to buy counterfeits.

Tourist shopping behaviour is considered to represent an action which is completely distinct from tourists' ordinary routine (Oh et al., 2004). This fact and the status that street markets have achieved as tourist attractions in Turkey and Portugal justifies the sample population focussing only on foreign tourists visiting the most popular paradises for counterfeits - the Algarve in Portugal and Bodrum in Turkey. The stalls sell mostly bric-a-brac ranging from the usual stuff, to fake clothes, toys and antiques. These street markets where haggling is welcome have become a tourist attraction in both countries, attracting millions of tourists over the years.

However, buying counterfeit products in a street market is rarely studied in a tourism context. Thus, this study aims not to offer value judgments about consumers who shop for counterfeits in street markets; rather, it analyses tourists' attitudes towards street markets in a specific holiday context. A group of tourists representing various European nationalities and visiting a particular destination both in Portugal and Turkey were selected as the sample population of this study and data were collected while the respondents were about to complete their holiday and when heading back to their home country from each destination.

\section{Literature review}

This study, aside from its general objectives, aims to consolidate existing findings supporting a comprehensive model of antecedents and drivers in a volitional purchase of counterfeit products in tourism contexts, at street markets. Bearing this purpose in mind, there are a number of past research outputs that should be pointed out as a basis for the conceptual model. First, past research demonstrates that shopping is one of the most important activities for tourists (Timothy, 2005; Kinley et al., 2002). As mentioned by Turner and Reisinger (2001), a trip is not complete without shopping. In addition, tourists tend to behave quite differently while on a vacation (Oh, Letho, \& O'Leary, 2004; Yuksel, 2004; Kozak \& Tasci, 2005; Timothy, 2005). Their preferences to bargain and to have what is inaccessible to them in their home countries are also evident, as is the case of counterfeits (Jansen-Verbeke, 1994; Kozak, 2015; Anti-Counterfeiting Group, 2009). Eisend and SchuchertGüler (2006, p. 14) argue that the situational context determines the likelihood of buying counterfeits:

I have sympathy for the kids dealing with the products; it is easier to shell out money when you're on a holiday; I don't want to be seen by people who know me; I don't feel like an outsider if I am not that conscious of law and order; to haggle is stressful but it's fun.

These reasons critically demonstrate that tourists are more likely to buy counterfeit products. Moreover, the AntiCounterfeiting Group (2009) refers to this propensity as the "holiday mood effect," that is, a MV (Moral values) "free pass" for tourists while on holidays. Also, the geographical context is critical if we consider that tourists are willing to change their attitudes as a result of disruption between their cultural background and the culture of their destination (Zhan \& He, 2011). Further this is the opportunity to interact with the locals (Timothy, 2005).

Second, markets are the perfect outlet for counterfeit products since consumers are more supportive of counterfeit products in markets than in shopping malls (Tom, Gail, Garibaldi, Zeng \& Pilcher 1998). In the same vein, Casola, Kemp, and Mackenzie (2009) argue that consumers are more likely to purchase a counterfeit brand while in an appropriate and favourable shopping environment. Counterfeit products are very similar or indistinguishable from those with a registered trade mark (Cordell, Wongtada, \& Kieschnick, 1996). For this type of products, there are two types of consumers: deceptive and non-deceptive (Grossman \& Shapiro, 1988). The former group of consumers does not know that they are buying counterfeits, while the latter group knows. A large proportion of consumers know what they are buying (Grossman \& Shapiro, 1988). Furthermore, demand for counterfeit consumption has a tendency to increase, due to the widespread occurrence of goods in those markets (Eisend \& Schuchert-Güler, 2006). The twin motivations of being in tune with fashion and achieving the prestige of being seen wearing a 
luxury brand explains a large proportion of the growth in the worldwide trade of counterfeits (Wee, Tan, \& Cheok, 2005; Tom, et al., 1998). Shopping prestige motivations were considered as one of the main drivers of tourists whereas the quest for authenticity reasons the choice for buying in street markets (Timothy, 2005; Butler, 1991).

Third, there are myriad reasons that drive consumers to knowingly buy counterfeits in street markets. The AntiCounterfeiting Group (2009, p. 9) argues that attitudes towards counterfeit products could be summed up by a lack of resources and remorse, such as:

There's no way on earth I'd be able to afford the real thing, so I'm not harming anyone, There is no risk I'm going to go to jail for this, and if it was a big deal, the government would be doing something about it; What's unethical is that I cannot afford the item I want!

This attitude towards counterfeits indicates three main motives: Price consciousness (PC) (e.g. Bloch, Bush, \& Campbell, 1993; Albers-Miller, 1999); perceived utility (PU) (Bloch et al., 1993; Ang, Hoon, \& Siok, 2001; Lichtenstein, Netemeyer, \& Burton, 1990; Lloyd et al., 2011); and moral consciousness (Steenhaut \& van Kenhove, 2006; Shoham, Ruvio, \& Davidow, 2008). Furthermore, the importance of luxury counterfeit products justifies Status consciousness (SC) as a major moderator of the willingness to buy counterfeit products (Grossman \& Shapiro, 1988; Cordell \& Wongtada, 1991).

PC is defined as the willingness to pay lower prices or at the least the fair price for the product they are buying (Lichtenstein, Ridgway, \& Netemeyer, 1993; Sinha \& Batra, 1999). This construct started to be approached in microeconomic theory represented by Varian (2010) as the consumer surplus, or the maximum price the consumers are willing to pay for having a certain product. The results of previous research show that the consumer's level of PC) is higher among deal-prone consumers (Babakus, Tat, \& Cunningham, 1988), those who believe less in price-quality associations (Lichtenstein, Bloch, \& Black, 1988).

PU is the "consumer's overall assessment of the utility of a product based on perceptions of what is received and what is given" (Zeithaml, 1988). PU is conceived as a trade-off of give and get attributes/utility, which are the benefits that a consumer receives from a product or service (Zeithaml, 1988). Kikuchi and Ryan (2007) prove that visitors from Europe look for value for money when buying objects at street markets. The boundaries between this construct and PC are very weak. Ruiz, Gremler, Washburn, and Carrión (2008) argue that current conceptualizations of PU may covary with PC dimensions if not modelled as a formative component construct. Previous studies generally adopt dimensions such as product quality, service quality and price as dimensions of PU that mainly focus on monetary and functional value (Timothy, 2005). However, reliance on these is insufficient to capture the domain of the construct, given that the retail experience for the customer is broad and that the emotional or hedonic type of value is unfortunately overlooked. Retail experience encompasses activities including navigating the store, finding merchandise, interacting with store employees, returning merchandise (Dabholkar, Thorpe, \& Rentz, 1995), all of which impact PU, and some are particularly important to emotional value.

Moral values (MV) reckons on Kohlberg's (1976) moral competence theory suggesting that personal behaviours are dictated on the basis of a subjective sense of justice (Cordell \& Wongtada, 1991). Willing to purchase of counterfeits falls into the class of non-normative consumer behaviour (Cordell \& Wongtada, 1991). Tolerance of and participation in non-normative behaviour is often justified by neutralization, whereby the perpetrator excuses him/ herself from blame by denial of wrong or deflecting blame to the victim (Cordell, Wongtada, Kieschnick, 1996). This moral permissiveness reflects a double standard whereby consumers hold themselves to lower ethical standards than the business with which they exchange. A frequent excuse for such moral laxity is that the consumers need to neutralize the unfair advantages and tactics that the seller possesses (DePaulo, 1986).

$\mathrm{SC}$ refers to respect. Furthermore, it involves a social ranking or recognition that a group would award to an individual (Eastman, Fredenberger, Campbell, \& Calvert, 1997), which is irrespective of social and income level. Consumption to achieve status is that consumption which consumers undertake to show visible signs of ostentation, able to confer to them the respect and reference by their peers (Eastman et al., 1997). In this research we adopted the SC scale of Eastman et al. (1997) to measure if the most statusconscious consumers are likely to be more attracted to counterfeits to signal their purchasing power at low expense. This assumption was posited by Timothy (2005) who outlines that Economic prestige had lead tourists to buy bargains, outlets, pirated goods and replicas at the destination.

Our comprehensive model, which is explained in the next section, departs from the assumption that tourists' decisions regarding counterfeit shopping are logical and volitional (Gentry et al., 2001; Casola et al., 2009).

\section{Methodological model and hypotheses}

Attitude is defined as a latent construct that guides consumer behaviour (Fishbein \& Ajzen, 1975). Consumers' attitudes towards street markets are assumed to be related to price, the utility of the products, and social compliance with the norms of their peer groups. Attitudes are also related to values, beliefs, intentions, and behaviours, as in the case of counterfeiters. This research focuses on personal attitudes, and as such the model presented hypothesizes that attitude towards street markets influence tourists' satisfaction and their intentions regarding repeat visitation or recommending the experience of shopping in street markets to others. When brand status is important for tourists they are more likely to buy in street markets to avoid being accomplices to snobbery or to the outrageous price of luxury branded goods (Wee, Tan, \& Cheok, 1995; Tom et al., 1998; Phau \& Teah, 2009).

Thus, SC also influences attitudes and purchasing intentions regarding counterfeits. Satisfaction with the shopping experience of counterfeits at the destination is introduced in the model as a proxy for tourists' attitudes that precede intentions. Fig. 1 illustrates the methodological model and hypotheses that demonstrate a relationship between the constructs considered. According to this perspective, the following hypotheses have been established:

Price is the main determinant of demand. This is also true for tourist shopping behaviour. Wu, Wall, and Pearce (2014) show that price, the fun of bargaining and the fake quality of products are the leading factors to motivate tourists to buy at a silk market. This is also the case for counterfeits where financial reasons are foremost in the purchase of counterfeit products. Rational consumer choice is based on assessing the cost/benefits of having a product. In the case of luxury branding, counterfeiters offer the brand and the social visibility of owning the insignia of a luxury brand, with similar functions, at a fraction of the price (Phau \& Teah, 2009). Therefore, consumers operating within the category of PC are those who are concerned with the balance between product, price, and quality (Wee et al., 1995). As mentioned by Tom et al., (1998), these are the individuals who would prefer to buy counterfeits to avoid the outrageous prices charged by original trademarks. Tsang, Tsai, and Leung (2011) prove that value for money is one of the most important factors to bargaining intentions. 


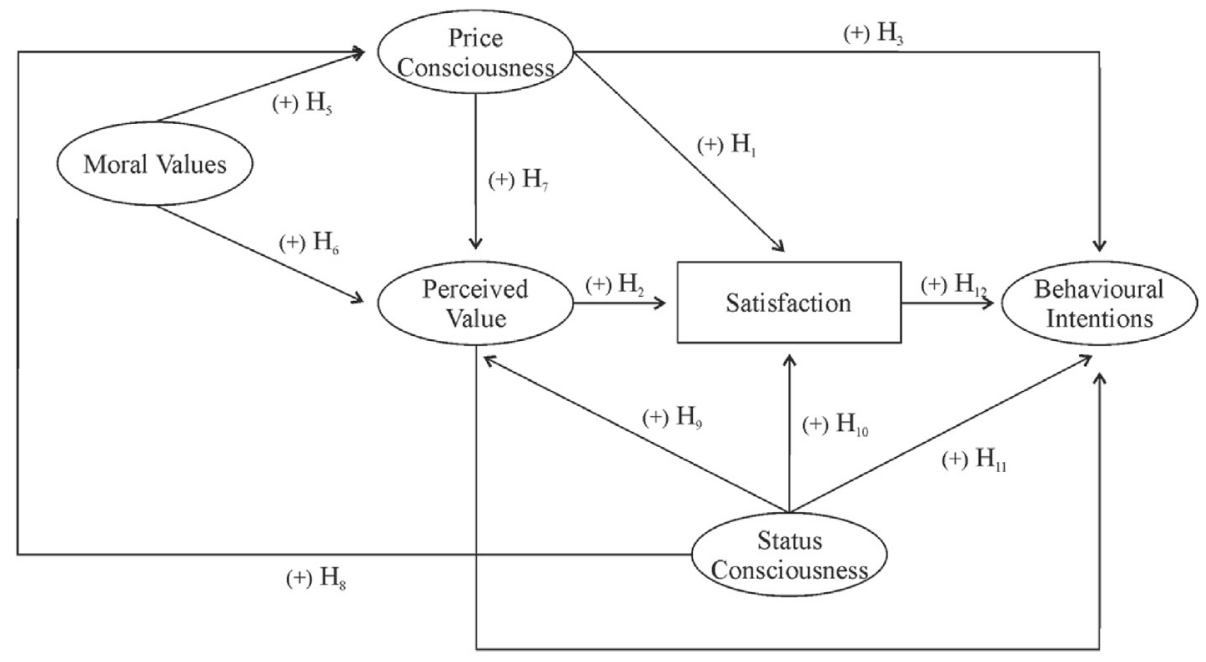

(+) $\mathrm{H}_{4}$

Fig. 1. Conceptual framework.

H1. PC positively influences overall satisfaction towards counterfeits bought at street markets at the destination.

H2. PU positively influences overall satisfaction with the street markets visited.

As luxury goods are very dependent on fashion, they are not expected to last long enough to justify the price level (Wee et al., 1995; Gentry et al., 2001). In this sense, purchasing counterfeits is more logical. The inferior quality is compensated for by the short time this product will remain in fashion. When perceptions about price and utility correlate at minimal levels, consumers are likely to be satisfied, and willing to expect a positive intention (Eisend \& Schuchert-Güler, 2006; Phau \& Teah, 2009).

H3. PU positively influences future behavioural intentions towards street markets at the destination.

H4. PC positively influences future behavioural intentions towards street markets at the destination.

Buying counterfeits represents an example of non-normative behaviour (Cordell et al., 1996), only excused by social tolerance, which tends to neutralize the unethical effect of these trades (Cordell et al., 1996). This behaviour is what the Anti-Counterfeiting Group (2009) mentions as a lack of remorse. A lack of remorse is assumed to be related to the ethics and MV of individuals, although in the majority of cases, moral rights surpass ethical standards of behaviour. Consumers tend to be more compliant with societal standards and more sensitive to interpersonal rejections than to the ethics of their behaviour (Hilton, Choi, \& Chen, 2004). However, the social sanction for being detected buying counterfeits instead of originals is relaxed while on holiday (Eisend \& Schuchert-Güler, 2006).

H5. MV positively influences PC of counterfeits bought at street markets at the destination.

H6. MV positively influences PU of counterfeits bought at street markets at the destination.

Tourists tend to assess value for money based on the best bargain price (Gentry et al., 2001). Considering this, tourists buy the counterfeit products that offer the best ratio for the overall benefit considering the associated costs (Zeithaml, 1988).
H7. PC positively influences PU of counterfeits bought at street markets.

Consumers utilize goods to communicate about social status (Belk, 1988). Counterfeits tend to preserve the physical replication of luxury goods, in particular the insignia, at a fraction of its real price (Cordell \& Wongtada, 1991; Tom et al., 1998). Thus, if counterfeit products are mistaken for originals, they will confer the status that consumers wish to have (Ang, Hoon, Eliot, \& Siok, 2001; Tom et al., 1998; Bloch et al., 1993), for a fraction of the price. In this sense, counterfeits are regarded as a cheaper substitute for status goods (Wee et al., 1995).

H8. SC positively influences PC of counterfeits bought at street markets at the destination.

H9. SC positively influences PU of counterfeits bought at street markets at the destination.

Status involves the recognition that an individual wishes to achieve within a peer group (Eastman et al., 1997). The desire to have this recognition, rather than being related to their social or income level, cross-cuts all human beings (Miller, 1991; Eastman et al., 1997). As a result, status consumers are more likely to buy counterfeits in order to have the visible symbols of luxury at a price that they are willing to pay (Hoe, Hogg, \& Hart, 2003).

H10. SC positively influences satisfaction regarding counterfeits at street markets at the destination.

H11. SC positively influences behavioural intentions regarding counterfeits at street markets at the destination.

The purchase of counterfeits is explained largely by satisfaction (Wee et al., 1995; Chang, 1998; Ang et al., 2001). In other words, the more satisfaction experienced by tourists, the greater the likelihood of repeat visitation or of word-of-mouth recommendation regarding these destinations in order to make a counterfeit purchase (Wee et al., 1995).

H12. Satisfaction with counterfeits at street markets positively influences behavioural intentions regarding a destination. 


\section{Research context and method}

\subsection{Research context}

Portugal and Turkey have a geographical situation that favours street markets. As they are popular destinations, tourists are one of the first targets of counterfeit sellers. In Turkey, the authorities estimate that counterfeits may be worth more than US\$6bn in 2011 and this figure has been increasing since 2010. The trade is roughly half of this value (US\$3bn) (www.cnnturk.com). Handbags are the most common counterfeit products made and sold in Turkey, but other products may be found as such as electronics, cosmetics, accessories, pharmaceuticals, textiles and alcohol. Traditionally, these products are sold on the street all along the Turkish coastline. Since the 15th century, Turkish street markets have attracted millions of tourists and visitors.

Portugal is a small country. Nevertheless, the amount of trade in counterfeits is estimated to be US\$3bn in 2011 (UNODC, 2011). Portugal is also known worldwide for its manufacturing culture of textiles, footwear and leather goods, as well as being a tourism destination. Together these factors contribute to the increasing number and variety of fake products sold in street markets and tourism areas. Clothing, shoes, handbags, belts, watches, perfumes and sunglasses are sold in street markets. Street markets in Portugal started in the 12th century with the "feira da ladra" market or "Thieves' Market" (in the original Portuguese, it is a woman thief!). This name was first mentioned in the 17th Century. This market still takes place twice a week on Tuesdays and Saturdays.

\subsection{Methods}

The sample population consisted of foreign tourists visiting two Mediterranean destinations in the summer of 2011 (July and August) - namely Algarve (Portugal) and Bodrum (Turkey). The sample was selected using a stratified random sampling approach, based on the shared nationalities of both countries. The strata were defined considering the number of overnights of each nationality in both countries. The sampling approach was based on binomial distribution with maximum dispersion of $50 \%$, which means that a tourist in Bodrum or in Algarve accounts for a probability of $50 \%$ of shopping for counterfeits at street markets at the destination. Overall, a total of 327 valid responses were collected, 189 in Algarve and 138 in Bodrum, representing a sampling error in the case of an infinite population of $5.4 \%$ and a confidence level of $95 \%$ $(\mathrm{p}=\mathrm{q}=0.5)$. Furthermore, we eliminated those questionnaires containing missing data in order to avoid bias. As suggested by Anderson, Tatham, and Black (1998), the analysis of data with missing values should be avoided since missing values influence the quality of the whole database. Further outliers were also eliminated and normal distribution of data was ensured.

A self-administered survey is of help in collecting data, and avoids any prejudice or assumptions about tourists' likelihood of buying counterfeits in street markets. As a screening question, the sample population included those who declared their familiarity with counterfeit shopping. The researchers distributed the questionnaires and then collected them at the airports of each destination at the time of departure. As a screening criterion, the researchers tried to approach international tourists over 18 years old, and who declared themselves to be on holidays with a duration of at least 3 days. These criteria may improve the reliability of data since the length of stay moderates tourists' perceptions of the place (Kozak, 2001). Table 1 displays the profile of respondents by each destination.

Despite the nature of different destinations, tourists visiting Algarve and Bodrum present a similar socio-demographic profile, and $\mathrm{x}^{2}$ tests indicate, as illustrated in Table 1 , that most of the characteristics of the respondents are homogeneous. Generally speaking, respondents were mostly women with an average age of 41 years in the Algarve, and 32 years in Bodrum. The nationalities concerned were mainly the British, Dutch and Belgians, representing the main tourist markets for both destinations, even though the sampling process does not adopt market shares per nationality. The majority of respondents were married and this tended to lead to the participants to travel with their families. Also, the majority of respondents was represented in an average income category (earning less than $€ 5000$ per month), employed, and with a university degree. The average length of stay was approximately two weeks. The vast majority of respondents had experience of shopping in markets as well as in stores. They decided to visit the local markets influenced by their families and friends once they had reached their hotels at the destination. In one way or another, approximately seven out of ten tourists were aware of the presence of counterfeit products and were likely to buy them. The majority of tourists only bought counterfeit products while on holiday $(73.5 \%$ out of those visiting Algarve and 70.9\% visiting Bodrum).

\section{Measurement constructs}

A two-step approach to SEM was used in this research, as recommended by Anderson and Gerbing (1988). The measurement model was specified and tested before the testing of the full structural model. The aim in developing the measurement models before the full structural model was to assess the validity and reliability of the constructs before their use in the full model

Table 1

Profile of respondents.

\begin{tabular}{|c|c|c|}
\hline & Algarve & Bodrum \\
\hline \multicolumn{3}{|l|}{ Age Groups $\left(X^{2}=37.170 ; p=0.000\right)$} \\
\hline less than 45 years old & $51.20 \%$ & $64.20 \%$ \\
\hline \multicolumn{3}{|l|}{ Gender $\left(X^{2}=0.205 ; p=0.651\right)$} \\
\hline Female & $63.00 \%$ & $58.70 \%$ \\
\hline \multicolumn{3}{|l|}{ Nationality $\left(X^{2}=1.4555 ; p=0.228\right)$} \\
\hline UK & $45.00 \%$ & $55.00 \%$ \\
\hline Netherlands & $13.20 \%$ & $9.40 \%$ \\
\hline Belgium & $5.80 \%$ & $5.10 \%$ \\
\hline \multicolumn{3}{|l|}{ Marital Status $\left(X^{2}=2.509 ; p=0.113\right)$} \\
\hline Married & $69.80 \%$ & $52.20 \%$ \\
\hline \multicolumn{3}{|l|}{ Education $\left(X^{2}=0.045 ; p=0.832\right)$} \\
\hline University & $65.60 \%$ & $62.30 \%$ \\
\hline \multicolumn{3}{|l|}{ Average income $\left(X^{2}=2.220 ; p=0.136\right)$} \\
\hline less than $5000 €$ & $61.10 \%$ & $71.30 \%$ \\
\hline \multicolumn{3}{|l|}{ Employment situation $\left(X^{2}=2.220 ; p=0.136\right)$} \\
\hline Employed & $73.50 \%$ & $72.50 \%$ \\
\hline Average Stay $($ days $)\left(X^{2}=0.291 ; p=0.590\right)$ & 14.00 & 11.00 \\
\hline \multicolumn{3}{|l|}{ Travelling companion $\left(X^{2}=48.587 ; p=0.000\right)$} \\
\hline Family & $86.80 \%$ & $51.40 \%$ \\
\hline \multicolumn{3}{|l|}{ Accommodation $\left(X^{2}=82.187 ; p=0.000\right)$} \\
\hline Hotels & $67.20 \%$ & $88.40 \%$ \\
\hline \multicolumn{3}{|l|}{ Where they shop $\left(X^{2}=33.880 ; p=0.000\right)$} \\
\hline Markets & $56.10 \%$ & $22.50 \%$ \\
\hline Both markets and stores & $42.90 \%$ & $68.80 \%$ \\
\hline \multicolumn{3}{|c|}{ How did they heard about counterfeit markets $\left(X^{2}=10.160 ; \mathbf{p}=0.001\right)$} \\
\hline at the hotel & $25.90 \%$ & $45.70 \%$ \\
\hline family/friends recommendation & $39.20 \%$ & $22.50 \%$ \\
\hline \multicolumn{3}{|c|}{ Familiarity with counterfeit products $\left(X^{2}=46.234 ; p=0.000\right)$} \\
\hline Perfect knowledge & $44.60 \%$ & $54.30 \%$ \\
\hline No knowledge & $35.40 \%$ & $27.50 \%$ \\
\hline \multicolumn{3}{|c|}{ How often do you buy counterfeit products? $(X 2=2.452 ; p=0.4849$} \\
\hline I only buy counterfeit products while on holidays & $73.50 \%$ & $70.90 \%$ \\
\hline I never buy counterfeit products & $14.30 \%$ & $14.60 \%$ \\
\hline I buy counterfeit products everywhere & $12.20 \%$ & $14.50 \%$ \\
\hline \multicolumn{3}{|l|}{ Counterfeit products bought } \\
\hline Cloth, bag, leather, bijouterie and watch, and souvenir & $86.00 \%$ & $79.00 \%$ \\
\hline
\end{tabular}


(Anderson \& Gerbing, 1988). Additionally, the sample was split into two sets comprising each of the destinations under analysis. Each set of data included 189 cases for Algarve and 138 for Bodrum to test the validity of the structural model (Byrne, 1989).

The first sample is treated as a "calibration" sample, and the second sample becomes the "validation" sample (Byrne, 1989). Both CFA and SEM models were first tested on the calibration sample and the goodness-of-fit of the model was analysed. Then, the model was tested for the validation sample. As the models present good fits in both samples, the validity of the overall model is supported. Further multi-group structural path analysis was performed to evaluate the invariance of path coefficients among the Algarve and Bodrum (Bollen, 1989). Although the homogeneity of tourist profile in Algarve and Bodrum is maintained, nonparametric tests show that their behaviours are quite different while visiting street markets (Table 2).

The sample obtained for each of the groups is enough to perform a multi-group analysis as degree of freedoms are not compromised by the number of hypotheses established. For instance, Macgowan and Newman (2005) perform a multi-group analysis with one group of 125 and another with 82 cases. First, a fully constrained, fully-saturated baseline model was established for both groups to examine the feasibility of the hypothesized path model presented in Fig. 1, by specifying the 12 direct paths and six error covariances (PC; PU, SC, MV, satisfaction, and behavioural intentions) and by imposing equality constraints on all direct paths and covariances. The test of critical ratio differences is used to determine the paths that present significant differences across both destinations. Releasing equality constraints for any given parameter indicates that the parameter in question differs significantly across those visiting Algarve and Bodrum (Byrne, 1989). Finally, the $\Delta S-B \quad \chi 2$ (scaled chi-squared difference) test was conducted to compare the null (i.e., fully-constrained, fully-saturated) model and the final model (i.e., released equality constraints).

The fit of measurement and structural models is determined by examining chi-square $\left(x_{2}\right)$ statistics that are generally affected by the sample size, the goodness-of-fit index (GFI), the comparative fit index (CFI), the Tucker-Lewis index (TLI), and the incremental fit index (IFI). Values of GFI, IFI, CFI and TLI range from 0 to 1 with values close to 1 indicating goodness-of-fit (Mulaik et al., 1989). Root Mean Square Error of Approximation (RMSEA) is also assessed. This measure, based on the non-centrality parameter, suggests that good models present an RMSEA of 0.05 or less. Unstandardized parameter estimates are used following the recommendation of Bollen (1989).

Values were measured by responses regarding 14 items derived from the literature, as was proposed by the authors. Respondents were asked to indicate the extent to which they would agree or disagree with the statements constructed to assess tourists' values in terms of counterfeits at street markets on a 5-point Likert scale ranging from 5 - totally agree" to " 1 - totally disagree". The set of factors used to measure latent constructs ranges from perceived benefits/price to the social embarrassments that purchasing counterfeit products may represent among the peer group.
Although the literature presents several suggestions towards classifying those factors, the items included in the questionnaire were mixed to avoid stereotyped answers.

A previous exploratory factor analysis with a varimax rotation allowed the retention of 11 items hereafter grouped into two types of constructs - PC and PU. These factors together account for a variance explained of $56.2 \%$. The 11 factors retained presented factor loadings above 0.5 . The three factors not retained present factor loadings less than 0.5 , and are related to the situational context of this study as such as "I will be very upset if my friends realize that the products are not genuine"; "counterfeit is my only chance to have fashion brands" and "it is easy to have access to counterfeit products".

MV reckons on ethic and social compliance whereas the scale of ethical values presents this behaviour as negative. In this sense, social compliance was made up of items that would excuse tourists' non-normative behaviour. The scale comprises seven items from which exploratory factor and reliability analysis allowed us to retain three items. The items dropped relied mostly on excuses used to ease tourist behaviour, such as "original product manufacturers are blamed for charging exorbitant prices"; "I know that buying counterfeit products is not socially acceptable"; and "I buy counterfeit products because everybody does it".

Furthermore, our scale comprises SC measures organized into seven items including self-expression (value-expressive function) and self-presentation (social-adjustive function). Items used to measure the social-adjustive function attempt to measure the extent to which they are motivated to consume luxuries to conform with their peers (Wilcox, Hyeong, \& Sankar, 2009), whereas items assessing value-expressive function assess how consumers communicate with others (Wilcox et al., 2009). A preliminary exploratory factor analysis groups both functions into one single component accounting for $66.8 \%$ of total variance explained. This result may suggest that self-expression and self-presentation yield the same weight of importance.

The overall satisfaction with their experiences of counterfeit markets was assessed on a 5-point Likert scale ranging between " 1 very dissatisfied" at the low end and "5- extremely satisfied" at the high end. Items to measure the behavioural intentions of recommendation and repeat visitation were adapted to ascertain the impact of their experiences at the counterfeit markets (I will recommend the market to others, I will plan to shop at the market when visiting this place again) on a 5-point scale of "1- not at all at" the low end and "5- definitely" at the high end. These questions are similar to the criteria used in other studies (e.g. Bigné, Andreu, \& Gnoth, 2005). Table 3 shows the resulting measurement constructs after confirmatory factor analysis which allows determination of how the items may differ in each destination.

\section{Results}

To test the structural model outlined in Fig. 1, this study followed the two-step approach described. A confirmatory factor analysis for the whole sample was estimated and all the factors freely

Table 2

Non parametric tests for the latent constructs.

\begin{tabular}{|c|c|c|c|c|}
\hline & Mann-Whitney U & Standardized test statistic & Asymptotic Sig.(2 sided test) & $\mathrm{HO}$ \\
\hline Price Consciousness & $10,353.5$ & -3.351 & 0.001 & Rejected \\
\hline Perceived Utility & 10,740 & -2.882 & 0.004 & Rejected \\
\hline Moral Values & $11,113.5$ & -2.409 & 0.016 & Rejected \\
\hline Status Consciousness & 16.661 & 4.440 & 0.000 & Rejected \\
\hline Behavioural Intentions & 9512 & -4.343 & 0.000 & Rejected \\
\hline
\end{tabular}

HO - The distribution of variables are the same across categories of place. 
Table 3

Measurement scale properties.

\begin{tabular}{|c|c|c|c|c|c|}
\hline & & \multicolumn{3}{|l|}{ Authors } & \multirow[b]{2}{*}{$\mathrm{P}$} \\
\hline & & & $\begin{array}{l}\text { Standardized } \\
\text { estimate }\end{array}$ & S.E. & \\
\hline I can get a copy for less with similar benefits & $\begin{aligned} \leftarrow & \text { Price } \\
& \text { Consciousness }\end{aligned}$ & $\begin{array}{l}\text { Gentry et al. (2001) Cordell et al. } \\
\text { (1996) }\end{array}$ & 0.715 & & \\
\hline $\begin{array}{l}\text { Counterfeit is my best option since I am not willing to pay what the original brand } \\
\text { producers want }\end{array}$ & $\begin{aligned} \leftarrow & \text { Price } \\
& \text { Consciousness }\end{aligned}$ & Cordell et al. (1996) & 0.701 & 0.077 & $* * *$ \\
\hline I feel that counterfeit products worth the money I paid & $\begin{aligned} \leftarrow & \text { Price } \\
& \text { Consciousness }\end{aligned}$ & Gentry et al. (2001) & 0.766 & 0.092 & $* * *$ \\
\hline When buying counterfeit products we get value for money and for the status & $\begin{aligned} \leftarrow & \text { Price } \\
& \text { Consciousness }\end{aligned}$ & $\begin{array}{l}\text { Grossman and Shapiro (1988); } \\
\text { Cordell et al. (1996) }\end{array}$ & 0.732 & 0.083 & *** \\
\hline I feel that counterfeit products have acceptable quality for me & $\begin{aligned} \leftarrow & \text { Price } \\
& \text { Consciousness }\end{aligned}$ & Gentry et al. (2001) & 0.792 & 0.088 & *** \\
\hline Counterfeit products usually meet my expectations & $\begin{aligned} \leftarrow & \text { Price } \\
& \text { Consciousness }\end{aligned}$ & Gentry et al. (2001) & 0.717 & 0.08 & *** \\
\hline $\begin{array}{l}\text { Counterfeiters are more efficient in terms of how they conduct business and are more } \\
\text { customer-oriented than the original manufacturers }\end{array}$ & $\begin{aligned} \leftarrow & \text { Price } \\
& \text { Consciousness }\end{aligned}$ & $\begin{array}{l}\text { Ang et al. (2001); Wee et al. } \\
\text { (1995) }\end{array}$ & 0.679 & 0.084 & *** \\
\hline I am smarter because I buy counterfeit products instead of original brands & $\begin{array}{l}\leftarrow \text { Perceived } \\
\text { Utility }\end{array}$ & $\begin{array}{l}\text { Gentry et al. (2001); Cordell et al. } \\
\text { (1996) }\end{array}$ & 0.69 & & \\
\hline Counterfeits of luxury brands provide similar functions to the original version & $\begin{array}{l}\leftarrow \text { Perceived } \\
\text { Utility }\end{array}$ & Gentry et al. (2001) & 0.741 & 0.100 & *** \\
\hline Counterfeits of luxury brands have similar quality to the original version & $\begin{array}{l}\leftarrow \text { Perceived } \\
\text { Utility }\end{array}$ & & 0.761 & 0.092 & *** \\
\hline Counterfeits of luxury brands are as reliable as the original version & $\begin{array}{l}\leftarrow \text { Perceived } \\
\text { Utility }\end{array}$ & & 0.670 & 0.098 & *** \\
\hline Buying counterfeits will damage interests and rights of legitimate/original manufacturer & $\leftarrow$ Moral Values & Fullerton et al. (1996) & 0.925 & & \\
\hline Buying counterfeits will hurt the luxury goods industry & $\leftarrow$ Moral Values & & 0.896 & 0.052 & $* * *$ \\
\hline Buying counterfeits infringes intellectual property & $\leftarrow$ Moral Values & & 0.650 & 0.052 & $* * *$ \\
\hline I enjoy it when people know I am wearing a luxury brand & $\begin{aligned} \leftarrow & \text { Status } \\
& \text { Consciousness }\end{aligned}$ & Wilcox et al. (2009) & 0.763 & & \\
\hline I like to be seen wearing luxury brands & $\begin{aligned} & \leftarrow \text { Status } \\
& \text { Consciousness }\end{aligned}$ & & 0.722 & 0.041 & *** \\
\hline Luxury brands help me fit into important social situations & $\begin{aligned} \leftarrow & \text { Status } \\
& \text { Consciousness }\end{aligned}$ & & 0.805 & 0.056 & $* * *$ \\
\hline Luxury brands are a symbol of social status & $\begin{aligned} \leftarrow & \text { Status } \\
& \text { Consciousness }\end{aligned}$ & & 0.750 & 0.08 & *** \\
\hline Luxury brands help me express myself & $\begin{aligned} \leftarrow & \text { Status } \\
& \text { Consciousness }\end{aligned}$ & & 0.931 & 0.058 & $* * *$ \\
\hline Luxury brands help me communicate my self-identity & $\begin{aligned} \leftarrow & \text { Status } \\
& \text { Consciousness }\end{aligned}$ & & 0.952 & 0.061 & $* * *$ \\
\hline Luxury brands reflect the kind of person I see myself to be & $\leftarrow \begin{array}{l}\text { Status } \\
\text { Consciousness }\end{array}$ & & 0.766 & 0.061 & *** \\
\hline I will recommend the market to others & $\begin{array}{l}\leftarrow \text { Behavioural } \\
\text { Intentions }\end{array}$ & Bigné et al. (2005) & 0.883 & & \\
\hline I will plan to shop at the market when visiting this place again & $\begin{array}{l}\leftarrow \text { Behavioural } \\
\text { Intentions }\end{array}$ & & 0.877 & 0.106 & *** \\
\hline
\end{tabular}

$\mathrm{CFI}=0.9 ; \mathrm{TLI}=0.89 ; \mathrm{RMESA}=0.05 ; \mathrm{IFI}=0.89 ; \mathrm{GFI}=0.801$.

correlated. The measurement model presents a chi-square of 401.418 ( $\mathrm{df}=202, \mathrm{p}=0.000$ ) suggesting that the model is nonsignificant, although other fit measures show acceptable indices $\mathrm{CFI}=0.958, \mathrm{GFI}=0.906, \mathrm{TLI}=0.948$, and $\mathrm{IFI}=0.959$, and RMSEA presents a reasonable value of about 0.055 . Thus, the measurement model fits suggested that the factor structure was reliable. Despite these results, the discriminant validity and reliability of the measurement model was tested at the global level and both discriminant and convergent validity were ensured. Thus, we could assume that the presented factor structure provides a good fit to data across both destinations.

To test the equivalence of item measurements across samples, we applied a more stringent procedure in which all paths (i.e. factor loadings, variances, and covariances) in the model were constrained to be equal for both samples. As can be seen in Table 2, items capturing PC, PU, moral beliefs, SC, satisfaction, and behavioural intentions showed good measuring properties. The final measurement model was found to fit statistics indicating that the model fits the data within the established guidelines $(\mathrm{CFI}=0.9$; $\mathrm{TLI}=0.89$; RMESA $=0.05$; IFI $=0.89$; GFI $=0.801$ ). In addition, convergent and discriminant validity of the measurement model was also evaluated, suggesting that the measurement model presents convergent and discriminant validity, as illustrated in Table 4. Therefore, we proceeded with the estimation of the structural model.

The PC factor included items to measure the cost/benefit approach that the rational consumers followed ( $\alpha$ was about 0.9 ). PU comprises the indistinguishable or very similar quality of counterfeits, making them almost perfect substitutes for the

Table 4

Scale's convergent and discriminant validity for the whole sample.

\begin{tabular}{lllllllll}
\hline & Cronbach's alpha & CR & AVE & BI & PC & MV & PU & SC \\
\hline BI & 0.893 & 0.873 & 0.774 & 0.154 & 0.076 & 0.880 & & \\
PC & 0.871 & 0.888 & 0.533 & 0.508 & 0.182 & 0.392 & 0.730 & \\
MV & 0.859 & 0.869 & 0.694 & 0.020 & 0.010 & 0.053 & 0.058 & 0.833 \\
PU & 0.83 & 0.808 & 0.513 & 0.508 & 0.182 & 0.301 & 0.713 & 0.140 \\
SC & 0.941 & 0.933 & 0.668 & 0.108 & 0.060 & 0.235 & 0.251 & 0.113 \\
\hline
\end{tabular}

Note: diagonal values represent the squared root of shared variance between constructs. CR Composite reliability. AVE: average variance extracted. BI behavioural intentions; PC price consciousness; MV. moral values. PU. perceived Utility. SC. Status consciousness. Correlation matrix. 
genuine goods ( $\alpha$ was about 0.8 ), as in Gentry et al. (2001). MV focused mainly on the awareness of the damage that counterfeits may cause in the industry of luxury good production ( $\alpha$ is 0.85 ), this is a major concern of Fullerton, Kerch, and Dodge (1996). SC played a role for tourists visiting street markets, as far as the selfexpression of status is concerned ( $\alpha$ was above 0.9 ), as in Wilcox et al. (2009). Finally, behavioural intentions comprised the intention to return with the explicit objective of shopping at street markets, as well as tourists' willingness to recommend these markets to family and friends.

Table 5 shows the reliability properties for the different scales, which were evaluated by means of Cronbach's alpha and composite reliability. The results were greater than the recommended threshold values for both indicators, as was the shared variance between constructs (average variance extracted). In addition, discriminant validity was tested by comparing the constructs' squared correlations with the shared variance among them. The diagonal elements in Table 4 demonstrate the squared root of Average Variance Extracted (AVE), which must be larger than the off-diagonal elements to establish the existence of discriminant validity (Fornell \& Larcker, 1981).

As Table 5 illustrates, there are no validity concerns with the factor structure derived; thus, the structural model is able to be estimated. The theoretical model was tested first separately for goodness of fit to each group through a structural equation model. In both cases, the goodness-of-fit measures are good $(\mathrm{CFI}=0.9$; $\mathrm{TLI}=0.94 ; \mathrm{RMESA}=0.04 ; \mathrm{IFI}=0.95 ; \mathrm{GFI}=0.85$ ). The following step proceeded with estimation of the path model through multigroup analysis.

The first model was a baseline model, in which the structural model was simultaneously estimated for both places. The effects of PU, PC, SC and MV on satisfaction and behavioural intentions were freely estimated across the groups. The two-group model provided a satisfactory fit for the data. The second model constrained all the beta coefficients to be equal across the two groups. The equivalence of all parameters assumed no difference between the two groups. The analysis then compared the constrained model with the baseline, and the difference in chi-square - the likelihood ration (LR) - testing the null hypothesis that the parameters were equivalent. In this study, the LR test was $44.863(d f=27, \mathrm{p}=0.000)$, suggesting that the beta coefficients were different across the two groups. To examine the path parameters where the models are different, the critical ratios of differences among all pairs of free parameters were analysed. Significant differences would suggest that specific structural paths were different for the two groups. Table 6 shows beta coefficients that are significantly different across the two groups.

As illustrated in Table 6, the path from "SC" to "Behavioural Intention" $(z=-3.12)$, as well as the path from "PU" to "Behavioural Intention" ( $z=2.79)$, and the path from "PC" to "Satisfaction" $(z=-1.924)$ are significantly different across the two destinations. The other paths remain unconstrained, since the results present evidence of significant differences across the groups. Table 6 shows the estimation results. Overall, all the hypotheses are estimated. Nevertheless, beta coefficients presenting as not statistically significant for both groups were eliminated from further procedures to improve the general fit of the model. The final model presents a chi-square of $722.839(d f=444, \mathrm{p}=0.000)$ which is not significant due to the sample dimension, although CFI $=0.945$, IFI $=0.946$, $\mathrm{GFI}=0.847$ and TLI $=0.932$, present good indices, as does the fact that the RMSEA was 0.044 .

The results where beta coefficients are equivalent for both destinations suggest that the main effect of "PC" on "PU" is positive and significant $(b=0.61, p<0.01$ ), supporting H7. This finding is in accordance with Tom et al. (1998) who suggest that smart shoppers tend to assess their purchases within the price paid vis-à-vis the quality received (Zeithaml, 1988; Bian \& Moutinho, 2009). Thus, it could be expected that these values are correlated. Similarly, "SC" influences "PU" positively and significantly ( $\mathrm{b}=0.407, \mathrm{p}<0.01$ ), supporting H9. This result suggests that counterfeit purchases are able to confer status on consumers (Grossman \& Shapiro, 1988). Furthermore, it also reinforces the idea that luxury counterfeits mimic the originals so well that they may be seen as substitutes (Cordell et al., 1996). "SC" also influences "Satisfaction" in a positive and significant direction ( $\mathrm{b}=0.115, \mathrm{p}<0.01$ ). Thus, H10 is supported. The positive correlation found in this path substantiates the status utility that counterfeit products could provide at half the price (Grossman \& Shapiro, 1988).

Furthermore, "SC" significantly influences "Behavioural Intentions", even if at the destination level this path is positive for Algarve and negative for Bodrum, suggesting that H11 is mixed.

Furthermore, "MV" influences "PU" positively and significantly ( $b=0.201, p<0.05$ ), but not "PC". Hence, H6 is supported but H5 is not supported. This result is surprising, since it would be expected that the more aware consumers are about the damage that their behaviour could cause in the economy, the less willing they will be to buy counterfeits (Fullerton et al., 1996). This positive path may suggest that moral reasoning is surpassed by the opportunity of having a product very similar to the original. This behaviour may be due to the innovation that these markets have experienced that enables the conception of counterfeits almost indistinguishable from the original products (Lefkoff-Hagins \& Mason, 1993). Otherwise, this result may suggest that even when aware of their non-normative behaviours, tourists do not feel guilty at all. As the Anti-Counterfeiting Group (2009) mentions, this behaviour represents a lack of remorse. Further research is needed to confirm why this path is positive. Not surprisingly, the path from satisfaction to behavioural intentions is positive $(b=0.924, p<0.01$ ), which supports H12. This finding suggests that assessing tourists' experiences at street markets, while on holidays, may lead to a spill-over

Table 5

Critical ratios difference test.

\begin{tabular}{|c|c|c|c|c|c|c|c|}
\hline & & & \multicolumn{2}{|l|}{ Algarve } & \multicolumn{2}{|l|}{ Bodrum } & \multirow[t]{2}{*}{ z-score } \\
\hline & & & Estimate & $\mathrm{P}$ & Estimate & $\mathrm{P}$ & \\
\hline Perceived Utility & $\leftarrow$ & Price Consciousness & 0.655 & 0 & 0.573 & 0 & -0.604 \\
\hline Status Consciousness & $\leftarrow$ & Perceived Utility & 0.509 & 0 & 0.275 & 0.004 & -1.565 \\
\hline Satisfaction & $\leftarrow$ & Price Consciousness & 0.408 & 0 & 0.247 & 0 & $-1.924^{*}$ \\
\hline Satisfaction & $\leftarrow$ & Status Consciousness & 0.122 & 0.008 & 0.114 & 0.064 & -0.11 \\
\hline Behavioural Intentions & $\leftarrow$ & Satisfaction & 0.933 & 0 & 0.876 & 0 & -0.314 \\
\hline Behavioural Intentions & $\leftarrow$ & Perceived Utility & -0.151 & 0.174 & 0.297 & 0.01 & $2.79^{* * *}$ \\
\hline Moral values & $\leftarrow$ & Perceived Utility & 0.341 & 0.012 & 0.021 & 0.889 & -1.591 \\
\hline Behavioural Intentions & $\leftarrow$ & Status Consciousness & 0.206 & 0.006 & -0.218 & 0.054 & $-3.12^{* * *}$ \\
\hline
\end{tabular}

Notes: ${ }^{* * *}$ p-value $<0.01$; ${ }^{* *}$ p-value $<0.05 ;{ }^{*}$ p-value $<0.10$. 
Table 6

Path model parameter estimates.

\begin{tabular}{|c|c|c|c|c|c|c|c|c|}
\hline & & & \multicolumn{3}{|l|}{ Algarve } & \multicolumn{3}{|l|}{ Bodrum } \\
\hline & & & Estimate & Standard error & $P$ & Estimate & Standard error & $P$ \\
\hline Perceived Utility & $\leftarrow$ & Price Consciousness & 0.61 & 0.068 & $* * *$ & 0.61 & 0.068 & $* * *$ \\
\hline Perceived Utility & $\leftarrow$ & Status Consciousness & 0.407 & 0.078 & $* * *$ & 0.407 & 0.078 & $* * *$ \\
\hline Satisfaction & $\leftarrow$ & Price Consciousness & 0.4 & 0.06 & $* * *$ & 0.248 & 0.049 & $* * *$ \\
\hline Satisfaction & $\leftarrow$ & Status Consciousness & 0.115 & 0.035 & 0.001 & 0.115 & 0.035 & 0.001 \\
\hline Behavioural Intentions & $\leftarrow$ & Satisfaction & 0.924 & 0.085 & $* * *$ & 0.924 & 0.085 & $* * *$ \\
\hline Behavioural Intentions & $\leftarrow$ & Perceived utility & -0.129 & 0.104 & 0.218 & 0.342 & 0.121 & 0.005 \\
\hline Perceived utility & $\leftarrow$ & Moral values & 0.201 & 0.1 & 0.046 & 0.201 & 0.1 & 0.046 \\
\hline Behavioural Intentions & $\leftarrow$ & Status Consciousness & 0.209 & 0.077 & 0.007 & -0.217 & 0.102 & 0.033 \\
\hline
\end{tabular}

Notes: ${ }^{* * *}$ p-value $<0.01 ;{ }^{* *}$ p-value $<0.05{ }^{*}$ p-value $<0.10$.

effect triggered by word of mouth or even by a loyalty effect.

At the destination level, "PC" influences "Satisfaction," although this relationship demonstrates stronger values for the Algarve $(b=0.4, p<0.01)$ than for Bodrum $(b=0.248, p<0.01)$, supporting H1. This result supports the findings of previous research carried out by Phau and Teah (2009) among others, outweighing the role of price as a major driving force of demand for counterfeit purchasing (Grossman \& Shapiro, 1988). The small impact determines that Bodrum may be related to some tendency to exploit tourists that occurs in Turkey as argued by Kozak (2015), although further research is needed to confirm such a preliminary assumption.

Furthermore, SC influences "Behavioural Intentions". While for tourists visiting the Algarve this attribute presents a significant and positive influence $(b=0.209, p<0.01)$, for tourists visiting Bodrum it presents a significant but negative influence $(b=-0.217$, $\mathrm{p}<0.05)$. These results provide mixed support H11 even though in an opposite way. This result may suggest that counterfeit products found in the markets of the Algarve are mostly mimics of luxury goods whereas in Bodrum this behaviour is not so predominant. As declared by tourists in the questionnaire, most of their purchases in the Algarve consist of clothes, bags, jewellery, sunglasses and perfumes; in Bodrum tourists bought mostly gifts, spices, cigarettes, music, souvenirs, and bargains. This finding enables us to confirm that the markets in the Algarve have plenty of luxury counterfeits whereas in Bodrum piracy and bargains prevail. "PU" influences "Behavioural Intentions" positively, but only in Bodrum $(b=0.201$, $\mathrm{p}<0.01$ ). In the Algarve, this path is not significant and the empirical evidence partially supports $\mathrm{H} 4$.

The hypothesis $\mathrm{H} 2$ stating that "PU will influence satisfaction" is not confirmed, which is a signal that counterfeits do not outperform the quality of genuine articles (Cordell \& Wongtada, 1991), and the satisfaction with this shopping experience is only derived from the experience by itself and not from the products purchased. In the same sense, H3 - "PC" does not influence "Behavioural Intentions". This finding may be due to the situational context. The behavioural intention of tourists to revisit only for shopping is rationally unlikely and the intention to recommend is also unlikely because tourists were exploited, as claimed by Kozak (2015). SC is unlikely to influence "PC" (H8), probably because price is more irrelevant than the PU for luxury counterfeits.

\section{Conclusion and implications}

This study proposed and tested a research model that examines how PC and PU, as critical drivers of attitudes in street markets, may influence satisfaction and future intentions of volitional consumers. The model also considers the influence of SC and MV. This study has focused on tourists and their shopping attitudes towards street markets while on holiday. As a cross-national study in the Algarve and Bodrum, a multi-group analysis was conducted to reveal the heterogeneity that the situational context may have on tourists' shopping behaviour regarding counterfeits.

The present study has first demonstrated that price and PU are the two most important and undeniable marketplace cues. These cues provide temptations for consumers who decide to buy counterfeits by comparing price with value. Surrogated by their values, the place where they shop plays an active role in overall satisfaction. Results suggest that price is a major determinant for the overall assessment of tourist experiences in street markets in the Algarve, whereas this case is not as relevant in Bodrum. As an additional implication, the low price in the Algarve prevails, as opposed to the statement of the PU (quality) that triggers shopping decisions in Bodrum.

The study findings also suggest that higher levels of satisfaction are likely to influence tourists' willingness to return or recommend street markets in both destinations. Traditionally, street markets and counterfeit products are assumed to be a serious economic and social problem within the sustainable development of tourist destinations. The results of this study suggest that even non-ethical behaviour, such as counterfeiting, may also have some positive impacts in the form of spill-over, creating new and more numerous tourist groups or creating existing tourist groups.

Furthermore, this model sets forth the idea that MV are relaxed by the social convention of having what they could not have at the outrageous prices of genuine products. In the same vein, their willingness to demonstrate status influences utility perceptions, satisfaction and future intentions, as in Lee, Woodside, and Zhang (2013). These findings indicate a striving towards the social claim of status equity, that which Leibenstein (1950) calls the bandwagon effect, or in other words, "keeping up with the Joneses". Considering that consumers seek status and also value for money while intending to buy counterfeit products, two recommendations can be given for brand owners to discourage consumers from buying a possible counterfeit product either at home or on holiday. First, brand owners may overview their marketing strategies by lowering the level of prices to a reasonable level that can be supported by potential consumers who are willing to experience the real brands. Second, brand owners may develop new product categories in an upper quality and price level that can substitute the value of original brand categories.

As is usual in this type of research, a number of issues arose that may embody the context of future research. First, an attitude-based comparison between residents and tourists may shed light on the effect of this street market in tourism. Attitude-based comparisons are crucial to understand the differences in functioning between the two destinations, the Algarve and Bodrum. Second, understanding tourists shopping behaviour in their social and life style contexts are crucial to cluster the market. Third, qualitative techniques such as storytelling may unveil what quantitative techniques could not. 
The subject of counterfeit shopping acts as a tourist attraction. Nevertheless, more proactive actions should be taken by the authorities that are closing their eyes to this behaviour, which is now not exclusive to the local residents. One of the main reasons to engage in this behaviour is that every one does so; therefore, the ethical dimension is discharged regarding MV. Furthermore, the anti-counterfeit report (2008, p. 90 ) refers to the proposal that "there is no risk I'm going to go to jail for this, and if it was a big deal, the government would be doing something about it?". Therefore, the research problem deals with the lack of attention of the authorities, which leads to it becoming a victimless crime.

As a final remark, the breadth of our investigation was limited by sample size. Hence, generalizability to the whole population of consumers may be limited, although this sample can be used to develop further research on this issue. Our study focuses on identifying non-price determinants of counterfeit purchasing behaviour of tourists and not on predicting such behaviours. Thus, the research interest was in offering a different perspective on such behaviours, including the development and empirical testing of the operationalization of non-price constructs in this study. Furthermore, this research does not distinguish the different types of counterfeit products; rather, it focuses on the willingness to buy in counterfeits in street markets. The number of tourists that use these shopping spaces to buy local handicrafts and souvenirs (over $40 \%$ ) shows that the intention to visit these spaces is also regarded as a local heritage experience, as outlined by Thompson, Locander, and Pollio (1990). Our findings are preliminary in nature, and subject to further research. From the stage of intention to the stage of purchasing counterfeit products, future investigation is needed in order to test whether the products or fakes are consumeroriented. In particular, shopping experiences should be assessed throughout a sensorial and emotional level, considering different shopping context-bounds and social life-contexts, as stressed by Lee et al. (2013). Finally, the purchase of counterfeits is also dependent on several other variables including whether the individual has previous experience purchasing counterfeits, the extent of risk of social disapproval, income levels of individuals, and materialism. These are still relevant variables for tourist shoppers to be considered in future research, where the hidden cues of this behaviour should be revealed.

\section{Acknowledgement}

This research was granted by UID/ECO/04007/2013 CEFAGE. The authors wish to thank Eylin Babacan, Nur Kulakoğlu Dilek, Vânia Correia, Jessica Correia and Miguel Melo for their assistance in collecting the data.

\section{References}

Albers-Miller, N. (1999). Consumer misbehaviour: why people buy illicit goods. Journal of Consumer Behavior, 16, 273-287.

Anderson, J., \& Gerbing, D. (1988). Structural equation modeling in practice: a review and recommended two-step approach. Psychological Bulletin, 103, $411-423$.

Anderson, R., Tatham, R., \& Black, W. (1998). Multivariate data analysis (4 ${ }^{\text {th }}$ ed.). Upper Saddle River, NJ: Prentice Hall.

Ang, S., Hoon, P., Eliot, A., \& Siok, K. (2001). Spot the difference: consumer responses towards counterfeits. Journal of Consumer Marketing, 18, 219-235.

Anti-Counterfeiting Group. (2009). What do consumers really think about fakes? Available at: www.a-cg.com (Accessed 1304 15).

Babakus, E., Tat, P., \& Cunningham, W. A. (1988). Consumer perceptions of rebates. Journal of Advertising Research, 28(4), 45-50.

Belk, R. (1988). Situational variables and consumer behaviour. Journal of Consumer Research, 2, 157-164.

Bian, X., \& Moutinho, L. (2009). An investigation of determinants of counterfeit purchase consideration. Journal of Business Research, 62, 368-378.

Bian, X., \& Veloutsou, C. (2007). Consumers' attitudes regarding non-deceptive counterfeit brands in the UK and China. Brand Management, 14, 211-222.
Bigné, J., Andreu, L., \& Gnoth, J. (2005). The theme park experience: an analysis of pleasure, arousal and satisfaction. Tourism Management, 26, 833-844.

Bloch, P., Bush, R., \& Campbell, L. (1993). Consumer 'accomplices' in product counterfeiting. Journal of Consumer Marketing, 10, 27-36.

Bojanic, D. C. (2011). The impact of age and family life experiences on Mexican visitor shopping expenditures. Tourism Management, 32(2), 406-414.

Bollen, K. (1989). Structural equations with latent variables. New York: John Wiley.

Butler, R. W. (1991). West Edmonton mall as a tourist attraction. The Canadian Geographer, 35, 287-295.

Byrne, B. (1989). A primer of USREL: Basic applications and programming for CFA models. New York: Springer-Verlag.

Casola, L., Kemp, S., \& Mackenzie, A. (2009). Consumer decisions in the black market for stolen or counterfeit goods. Journal of Economic Psychology, 30, 162-171.

Chang, K. (1998). Predicting unethical behaviour: a comparison of the theory of reasoned action and the theory of planned behaviour. Journal of Business Ethics, 17, 1825-1834.

Chang, J., \& Chiang, C. H. (2006). Segmenting American and Japanese tourists on novelty-seeking at night markets in Taiwan. Asia Pacific Journal of Tourism Research, 11(4), 391-406.

Chang, J., \& Hsieh, A.-T. (2006). Leisure motives of eating out in night markets Journal of Business Research, 59(12), 1276-1278.

Chang, J., Min, J., Lin, Y., \& Chiang, C. H. (2007). Profiling Japanese tourists visiting night markets in Taiwan. Journal of Quality Assurance in Hospitality \& Tourism, 8(2), 25-44.

Cordell, V., \& Wongtada, N. (1991). Consumer responses to counterfeit products. In T. Childers, Terry L. Childers, Thomas Leigh, Steven Skinner, John G. Lynch, Susan E. Heckler, Hubert Gatignon, Ray P. Fisk, \& John Graham (Eds.), Marketing theory and application (pp. 247-251). Chicago: American Marketing Association.

Cordell, V., Wongtada, N., \& Kieschnick, R. (1996). Counterfeit purchase intentions: role of lawfulness attitudes and product traits as determinants. Journal of Business Research, 35, 41-53.

Dabholkar, P. A., Thorpe, D. I., \& Rentz, J. O. (1995). A measure of service quality for retail stores: scale development and validation. Journal of the Academy of marketing Science, 24(1), 3-16.

DePaulo, P. (1986). Ethical perceptions of deceptive tactics used by salespersons and customers: a double standard. In Proceedings American psychological association (pp. 101-103). Washington, DC.: American Psychological Association.

Eastman, J. K., Fredenberger, B., Campbell, D., \& Calvert, S. (1997). The relationship between status consumption and materialism: a cross-cultural comparison of Chinese, Mexican, and American Students. Journal of Marketing Theory and Practice, 5(1), 52-66.

Eisend, M., \& Schuchert-Güler, P. (2006). Explaining counterfeit purchase: a review and preview. Academy of Marketing Science Review, 12, 1-26.

Fishbein, M., \& Ajzen, I. (1975). Belief, attitude, intention, and behaviour: An introduction to theory and research. Reading, Mass: Addison-Wesley.

Fornell, C., \& Larcker, D. (1981). Evaluating structural equation models with unobservable variables and measurement error. Journal of Marketing Research, 18 $39-50$.

Fullerton, S., Kerch, K., \& Dodge, H. (1996). Consumer ethics: an assessment of individual behaviour in the marketplace. Journal of Business Ethics, 15, 805-814.

Tom, Gail, T. Garibaldi, B., Zeng, Y., \& Pilcher, J. (1998). Consumer demand for counterfeit goods. Psychology \& Marketing, 15(5), 405-421.

Gentry, J., Putrevu, S., Shultz, C., \& Commuri, S. (2001). How now Ralph Lauren? the separation of brand and product in a counterfeit culture. Advances in Consumer Research, 27, 258-265.

Grossman, G., \& Shapiro, C. (1988). Foreign counterfeiting of status goods. The Quarterly Journal of Economics, 103, 79-100.

Harrison, D. (1994). Tourism and prostitution: sleeping with the enemy?: the case of Swaziland. Tourism Management, 15(6), 435-443.

Henderson, J. C., Chee, L., Mun, C. N., \& Lee, C. (2011). Shopping, tourism and retailing in Singapore. Managing Leisure, 16(1), 34-68.

Hilton, B., Choi, C., \& Chen, S. (2004). The ethics of counterfeiting in the fashion industry: quality, credence and profit issues. Journal of Business Ethics, 55, 345-354.

Hoe, L., Hogg, G., \& Hart, S. (2003). Fakin' it: counterfeiting and consumer contradictions. In D. Turley, \& S. P. Brown (Eds.), European advances in consumer research (pp.60-67). UT: Association for consumer research.

Interpol. (2015). Intellectual property crime. Retrieved from http://www.interpol.int/ public/financialcrime/intellectualproperty/default.asp.

Jansen-Verbeke, M. (1994). The synergy between shopping and tourism. In W. F. Teobald (Ed.), Global tourism: The next decade (pp. 426-428). Oxford: Butterworth-Heinemann.

Kikuchi, A., \& Ryan, C. (2007). Street markets as tourist attractions e Victoria Market. 9 pp. 297-300). Auckland, New Zealand: International Journal of Tourism Research.

Kinley, T., Josiam, B. M., \& Kim, Y. (2002). Why and where tourists shop: motivations of tourist-shoppers and their preferred shopping center attributes. Journal of Shopping Center Research, 10, 7-28.

Kohlberg, L. (1976). Collected papers on moral development and moral education. Cambridge, MA: Center for Moral Education.

Kozak, M. (2001). Repeaters behaviour at two distinct destinations. Annals of Tourism Research, 28, 784-807.

Kozak, M. (2007). Tourist harassment: a marketing perspective. Annals of Tourism Research, 34(2), 384-399.

Kozak, M. (2015). Bargaining behaviour of British tourists and their shopping 
experiences on a vacation. Journal of Tourism and Travel Marketing. online first. Kozak, M., \& Tasci, A. (2005). Locals' perceptions of foreign tourists: a case study in Turkey. International Journal of Tourism Research, 7(4-5), 261-277.

Lee, G., Woodside, A. G., \& Zhang, M. (2013). Fashion shopping from a VNA perspective: telling the untold story. Journal of Global Fashion Marketing, 4(2), 67-73.

Lefkoff-Hagins, H., \& Mason, C. H. (1993). Characteristic, beneficial and image attributes in consumer judgments of similarity and preference. Journal of Consumer Research, 20, 100-110.

Lehmann, A. C. (1980). Tourists, black markets and regional development in West Africa. Annals of Tourism Research, 7(1), 102-119.

Leibenstein, H. (1950). Bandwagon, snob, and Veblen effects in the theory of conspicuous demand. Quarterly Journal of Economics, 64, 183-207.

Lichtenstein, Donald R., Bloch, P.h., \& Black, W. C. (1988). Correlates of Price Acceptability. Journal of Consumer Research, 15(2), 243-252.

Lichtenstein, D. R., Netemeyer, R. G., \& Burton, S. (1990). Distinguishing coupon proneness from value consciousness: an acquisition-transaction utility theory perspective. Journal of Marketing, 54, 54-67.

Lichtenstein, D. R., Ridgway, N. M., \& Netemeyer, R. G. (1993). Price perceptions and consumer shopping behavior: a field study. Journal of Marketing Research, 234-245.

Lloyd, A., Yip, L., \& Luk, S. (2011). An examination of the differences in retail service evaluation between domestic and tourist shoppers in Hong Kong. Tourism Management, 32, 520-533.

Macgowan, M. J., \& Newman, F. L. (2005). Factor structure of the group engagement measure. Social Work Research, 29(2), 107-118.

Miller, C. (1991). Luxury goods still have strong market despite new tax. Marketing News, 25, 1-7.

Mulaik, S. A., James, L. R., Van Alstine, J., Bennett, N., Lind, S., \& Stilwell, C. D. (1989) Evaluation of goodness-of-fit indices for structural equation models. Psychological Bulletin, 105, 430-445.

Oh, J. Y., Lehto, X. Y., \& O'Leary, J. T. (2004). Predictors of tourists' shopping behaviour: examination of socio-demographic characteristics and trip typologies. Journal of Vacation Marketing, 10, 308-319.

Phau, I., \& Teah, M. (2009). Devil wears (counterfeit) Prada: a study of antecedents and outcomes of attitudes towards counterfeits of luxury brands. Journal of Consumer Marketing, 26, 15-27.

Ruiz, D. M., Gremler, D. D., Washburn, J. H., \& Carrión, G. C. (2008). Service value revisited: specifying a high-order, formative measure. Journal of Business Research, 61, 1278-1291.

Ryan, C., \& Kinder, R. (1996). Sex, tourism and sex tourism: fulfilling similar needs? Tourism Management, 17(7), 507-518.

Shoham, A., Ruvio, A., \& Davidow, M. (2008). (Un)ethical consumer behavior: Robin Hoods or plain hoods? Journal of Consumer Marketing, 25, 200-210.

Sinha, I., \& Batra, R. (1999). The effect of consumer price consciousness on private label purchase. International Journal of Research in Marketing, 16(3), $237-251$.

Steenhaut, S., \& van Kenhove, P. (2006). An empirical investigation of the relationship among consumer's personal values, ethical ideology and ethical beliefs Journal of Business Ethics, 64, 137-155.

Thompson, C. J., Locander, W. B., \& Pollio, H. R. (1990). The lived meaning of free choice: an existential-phenomenological description of everyday consume experiences of contemporary married women. Journal of Consumer Research, 17 346-361.

Timothy, D. J. (2005). Shopping tourism, retailing, and leisure. Bristol: Channel View Publications.

Timothy, D. J., \& Butler, R. W. (1995). Cross-border shopping: a North American perspective. Annals of tourism research, 22(1), 16-34.

Tsang, N. K. F., Tsai, H., \& Leung, F. (2011). A critical investigation of the bargaining behavior of tourists: the case of Hong Kong open-air markets. Journal of Travel \& Tourism Marketing, 28(1), 27-47.

Turner, L., \& Reisinger, Y. (2001). Shopping satisfaction for domestic tourists. Journal of Retailing and Consumer Services, 8, 15-27.

UNODC, United Nations Office on Drugs and Crime. (2011). Estimating illicit financial flows resulting from drug trafficking and other transnational organized crimes (Report, Vienna).

Uriely, N., \& Belhassan, Y. (2006). Drugs and risk-taking in tourism. Annals of Tourism Research, 33(2), 339-359.

Varian, H. R. (2010). Intermediate microeconomics: A modern approach (8 Ed., p. 739). W.W. Norton \& Company.

Veloutsou, C., \& Bian, X. (2008). A cross-national examination of consumer perceived risk in the context of non-deceptive counterfeit brands. Journal of Consumer Behaviour, 7, 3-20.

Wang, D. (2004). Hong Kongers' cross-border consumption and shopping in Shenzhen: patterns and motivations. Journal of Retailing and Consumer Services, 11(3), 149-159.

Wee, C., Tan, S.-J., \& Cheok, K.-H. (1995). Non-price determinants of intention to purchase counterfeit goods. International Marketing Review, 12, 19-47.

Wilcox, K., Hyeong, M., \& Sankar, S. (2009). Why do consumers buy counterfeit luxury brands? Journal of Marketing Research, 46, 247-259.

World Travel and Tourism Council. (2015). Economic impact research. Retrieved from access in 13/04/2015.

Wu, M.-Y., Wall, G., \& Pearce, P. L. (2014). Shopping experiences: international tourists in Beijing's Silk market. Tourism Management, 41, 96-106.

Yuksel, A. (2004). Shopping experience evaluation: a case of domestic and international visitors. Tourism Management, 25, 751-759.

Zeithaml, V. A. (1988). Consumer perceptions of price, quality, and value: a meansendmodel and synthesis of evidence. Journal of Marketing, 52, 2-22.

Zhan, L., \& He, Y. (2011). Understanding luxury consumption in China: consumers perceptions of best-known brands. Journal of Business Research, 65(10), $1452-1460$.

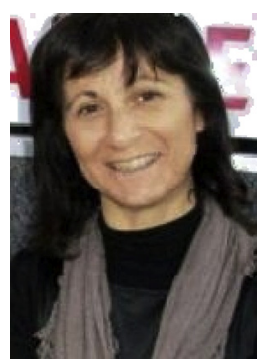

Antonia Correia is Professor of Tourist Behaviour and Tourism Economics, University of Algarve and European University, both in Portugal. Email: acorreia@ualg.pt. Her main research interests focus on consumer behaviour, tourism economics and modelling. She has a number of papers published in tourism, leisure and economics journals. Antonia is also a member of the editorial board of several journals including Journal of Travel Research, Journal of Business Research, Tourism Analysis, and Anatolia.

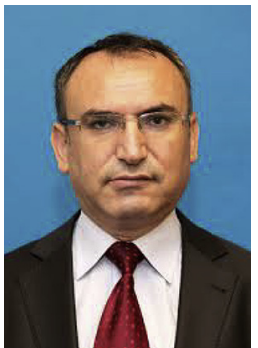

Metin Kozak is Professor of Tourism Marketing, Dokuz Eylul University, Turkey. His main research interests focus on consumer behaviour, benchmarking and competitiveness where he has a number of papers published in many tourism journals and conference papers presented. He sits on the editorial board of a broader number of journals including Annals of Tourism Research, Journal of Travel Research and Journal of Business Research and also acts as the co-editor of the journal Anatolia. 